\title{
Employment, environmental pollution and working class life in Tuzla, Bosnia and Herzegovina
}

\author{
Vanesa Castán Broto ${ }^{1}$ \\ University College London, UK
}

\section{Post-industrial landscapes of pollution}

On my first visit in April 2005, I approached the Bosnian city of Tuzla from the South, traveling by bus from Sarajevo. It was a wet and overcast day. The landscape imprints of the international conflict (19921995) haunted me alongside the road. This was mainly visible in scattered empty houses, boarded or without roofs, and the signs "Pazi Mine" ("Watch Mine"). The route involved crossing several towns shaped by their industrial heritage. Yet, nothing on this route prepared me for arrival in Tuzla. After climbing a long string of foothills and peaks the road suddenly descended to a narrow valley where the river Jala flows. From the bus, the valley was divided in two halves. On one side of the valley, small houses, both old and modern with their red roofs, spread up the Majevica Mountains onto every patch of available land, and giant apartment towers dominated the centre of the city. On the other side of the valley, at once grand and menacing, a power plant presides over the industrial complex that brought prosperity to this region during former Yugoslavia. The plant now stands as testimony to a dream of modernity never quite realised. Before reaching the bus station, I was saluted by the grand statue Rudarima, or 'coal miner', with his hand up, holding a rifle, and his other hand on miner's tools. The statue reminds the traveler of the centrality of the coal industry to the region.

The environmental degradation caused by Tuzla's coal-energy production is a compelling case of industrial pollution and economic decline, in which concerns for the environment and about unemployment are articulated simultaneously. The fundamental changes in the political and social structures of Bosnian society due to the break-up of Yugoslavia, the international conflict, and the subsequent economic transition, bring to the fore a number of challenges in the redefinition of post-industrial Tuzla. In particular, growing public concern about the environment in $\mathrm{BiH}$ has been accompanied by the decline of labor opportunities for the people of the region. The end of the war brought peace, but also a complicated system of government that accounts for $45.6 \%$ of the country's Gross Domestic Product (IMF 2010). In Tuzla the lack of public and private investment during the late 1990s and early 2000s stopped local development, with companies closing and rising unemployment. Foreign investment was welcomed but this often implied that objections and protests were silenced by a desperate attempt to revive the local economy: dramatic whispers over a glass of slivovica, the local plum brandy, and talk of the sale of emblematic chemical industries to foreign investors for symbolic prices.

The processes of industrialization and de-industrialization have left their mark on the physical environment. Most notably, there are serious pollution problems in the river Jala, the main surface water resource in the region; geo-technical disruptions caused by the extraction of salt and coal and the accumulation of coal ash in disposal sites (the city and its suburbs now have a serious sinking problem); and contaminants polluting the air with particulates, sulphur and carbon monoxide. In the urban suburbs near the coal-fired power plant, the physical effects of de-industrialization — black deposits in buildings and infrastructure, carbonate sediments in the local streams, landscape ruptures by land subsidence and coal ash accumulation - are even more salient. Pollution impacts are more noticeable in small suburban settlements around the power plant and the coal waste disposal sites whose inhabitants are directly affected by the material disruptions of pollution.

This is a land of contradictions, although, perhaps, no more contradictions than other areas where industrial decline and lack of investment have left behind a legacy of derelict land and environmental pollution. Yet, there is an amazing capacity of living forms to spread around and reinvent the landscape. During a visit to the disposal sites after four years of work, in August 2008, I was pleasantly surprised by wild vegetation growing and blossoming around the disposal sites. In the surrounding suburban villages (mjesna zajednica in Bosnian, or 'local communities'), life seemed to be thriving too: new houses were being built and old houses renovated; new business, shops and local cafes multiplied alongside the main road; home gardens and windows were colored by flowers and food crops. Life goes on, as well, under the shadow of the power plant. More puzzling, even, is the spontaneous cultivation by some local residents of some of the disposal sites where the power plant established a thin soil cover $(20$ to $50 \mathrm{~cm}$ ). Walking between maize and bean crops, I felt compelled to celebrate the ability of living creatures to go beyond the environmental destruction created by the industry, even though I share the concerns expressed by some people in those communities

\footnotetext{
${ }^{1}$ Dr Vanesa Castán Broto, Lecturer, Development and Planning Unit, University College London, 34 Tavistock Square, London, WC1H 9EZ, UK. E-mail: v.castanbroto "at" ucl.ac.uk. I am forever indebted to Kate Burningham, Lucia Elghali and Claudia Carter for their great support in doing this work. Thanks also to Simon Batterbury and an anonymous reviewer who help editing and improving the quality of the paper.
} 
who argue that by cultivating, selling and eating those crops, those who farm on the waste disposal sites are "endangering the whole community."

A Polish physicist who was researching the soil-pollutant relationships on the coal ash disposal sites asked me a rhetorical question: "How can people live like this?" She implied that local residents did not realize the potential dangers to which they were exposing themselves (or perhaps, she suggested, they did not care about them). This understanding of local perceptions of pollution resonates with the literature of psychological studies of risk perception, particularly on studies of individual reluctance to identify pollution in the home areas, often called the "neighborhood halo effect" (Bickerstaff and Walker 2001; Bickerstaff 2004). According to Bickerstaff (2004: 828) the literature on the social perception of risks has often interpreted these findings "as an expression of neighborhood or personal invulnerability in which the individual agrees to the presence of danger but denies that it will happen to them." Often, explanations for lack of awareness of pollution are associated with the idea that local residents will conform to the industry's requirements in exchange for jobs and economic security. The experience of a polluted space is intimately linked with their dependence on other stakeholders and their relative concerns for quality of life and livelihoods.

I suggest, however, that rather than being two separate issues caught up in an inverse relationship, quality of environment and security of employment are two closely related issues, and thus, local demands for environmental justice are often implicated with local demands for sustainable livelihoods in the same space. In other words, environmental quality and job provision are not viewed in a trade-off relationship; instead, both environmental quality and employment are part of the life of the community residents. Suggesting that local residents can turn (consciously or unconsciously) a blind eye to pollution in exchange for jobs, misrepresents the complexity of responses to residential pollution. Bringing together the political ecology on environmental conflicts and the social constructionist literature on public perceptions of environmental risks, this article argues that working class and the disadvantaged sections of society often are confronted by alliances between the industry, institutions and other stakeholders which may serve to legitimate a particular configuration of things in which the appropriation of some resources (i.e. land) by the industry is regarded as legitimate. However, these arrangements are unstable: they are subject to constant renegotiation between the social groups concerned. Thus, how the emergence of concerns about the local environment relates to preoccupations with the state of the local economy is related to the process whereby these relationships are constructed and re-negotiated.

In this context, the case of environmental pollution from coal-energy production in Tuzla is relevant for two reasons: first, it is a compelling case of industrial pollution and economic decline in which concerns for the environment and unemployment are articulated simultaneously. Second, the fundamental changes to the political and social structures of the Bosnian society due to the break-up of Yugoslavia, the international conflict and the subsequent economic transition, bring to the fore a number of challenges in the redefinition of post-industrial Tuzla. In particular, the growing public concern about the environment in Bosnia and Herzegovina that has emerged in the context of cultural and political change since the fall of former Yugoslavia is accompanied by the decline of labor as a central value in Bosnian society.

The paper is articulated in four parts. Section 2 explores the relationship between work, space and environment by presenting insights from political ecology and social constructionist literatures on public perceptions of environmental pollution. It concludes by returning to the classical idea of the social contract, as a metaphor for thinking about alternative arrangements to address both environmental pollution and employment concerns. Section 3 presents the case study of coal ash pollution in Tuzla, giving an overview of the case and summarizing how local residents put forward environmental and social justice arguments. The final discussion in Section 4 brings together the findings to highlight the dynamic relationships of local residents with their environment and the shortcomings of defining their arguments as a mere trade-off between either preserving environmental quality or creating jobs. Thus, I conclude, there is a need in Tuzla to redefine the role of industry within the social and environmental context in which it is established.

\section{Living and working with environmental pollution}

From a political ecology perspective, the putative dilemma between environmental quality and security of employment needs to be examined within specific political and economic contexts. How different social groups identify environmental problems has practical consequences. Environmental change rarely elicits a homogeneous response. What is presented as an environmental improvement by one group is often regarded as a problem by others (cf. Relph 1976; Greider and Garkovich 1994). Environmental protests are, therefore, not only about the putative conditions to which the claimants refer (environmental pollution) but also about other social factors that interact with these conditions (see for example Burningham and Cooper 1999; Hannigan 2006; Vatn 2005; Bickerstaff 2004). Emphasizing that the material world is subject to multiple social interpretations, these social constructionist studies highlight how environmental problems are defined in relation to other struggles, such as economic crises, political processes, social inequality and injustice.

This view has contributed studies of public understanding of environmental pollution that focus on how social interaction mediates the ways in which people come to know and make sense of environmental pollution, raising questions about dominant discourses of pollution and the policies they legitimate 
(Bickerstaff and Walker 2001, 2003). Social constructionist research exposes the limitations of various approaches that treat pollution as an isolated phenomenon, highlighting how the broad impacts of environmental pollution can only be understood within the socio-economic system in which they are identified. The social identification of a condition, in this case pollution, as a problem precedes the construction of the problem. Previous research has pointed to a variety of factors that may prevent individuals and social groups from identifying the condition of residential pollution, such as the amorphous and invisible nature of chemical exposure; the difficulties in diagnosing its presence and consequences; the reassurances (if present) by industry or local authorities about the safety of the area affected; or personal circumstances, such as the pride of ownership of a contaminated land parcel (for a detailed study see Edelstein 2004). In particular, case studies of areas where there are lower concerns (or even no concerns at all) about technological risks associated with environmental pollution and the siting of industrial facilities have interrogated whether certain groups are willing to accept the burden of a potentially harmful environmental risk, and why this occurs.

In a comprehensive ethnographic study of local attitudes toward nuclear facilities in La Hague, Normandy in France, Zonabend (1993) explained that people living in the vicinity of nuclear power stations and workers in high-risk industries "refuse to acknowledge the dangers of their job to the point where it is hard to get them to admit to taking essential safety precautions" (Zonabend 1993). To cope with the presence of the nuclear industry, he suggested, local residents and plant workers develop a discourse of safety that is, nevertheless, plagued by "furtive anxieties" toward the nuclear facilities. The study focused on the concealment of anxieties rather than on the initial question about the reasons why local residents and workers are willing to live with heightened environmental risks. Zonabend's study only begins to unpack why concerns about the local environment tend to be silenced or diminished when talking about one's own neighborhood, even though a similar concern may be recognized in the wider environment.

This issue has been the object of much interest in the literature on the social amplification of risks, generally concerned with "how risks and risk events interact with psychological, social, institutional, and cultural processes in ways that amplify or attenuate risk perceptions and concerns, and thereby shape risk behavior, influence institutional processes and affect risk consequences" (Kasperson et al. 2003: 2). In particular, this literature has developed a wide body of theory to explain the different mechanisms whereby the public develops individual or collective negative responses to technological risks (for a review see Kasperson et al. 2003). However, there is less research focusing on why residents in some locations present low-levels of or even no concern about particular technological risks. Often this relationship is simply explained by presuming a cost-benefit trade-off between the economic benefits provided by the industry locally and regionally and the emergence of concerns about environmental pollution among local communities: "Much economic theory of risk is based on the idea that views of risk and concern about local industrial hazards may be muted if that same industry is a major local employer" (Baxter and Lee 2004: 3). Moreover, it has been argued that when local residents rely on the industry to provide jobs, collective action proposals against environmental pollution, which could raise the level of local concern, may be silenced by the residents themselves (McGee 1999).

Using a social constructionist perspective to study local residents' concerns about a hazardous waste facility in The Swan Hills, Alberta, Canada, Baxter and Lee (2004: 22) argued that, locally, the industry was perceived as being "economically stabilizing" but the authors move away from the suggestion that perceived economic benefits were traded for environmental concerns by explaining that "the reluctance to express facility risk and safety concerns, latent or otherwise, may be traced to a community's historical and economic context, as well as the legacy of facility siting. In this case, a historically floundering local economy combined with a voluntary siting process set the stage for ongoing individual and social suppression of concern. Outsiders' negative perceptions of the facility were regarded as a threat, and thus highly contested locally, independently of the local perceptions of the landscape changes (see Baxter 2009 for a detailed analysis of the insider/outsider thesis). Moreover, local residents in disadvantaged communities may perceive outsiders' descriptions of their locality as offensive, particularly when they portray their home as "polluted" or "unhealthy" (Burningham and Thrush 2004). The local industry may be "naturalized" as part of the landscape in which the community is imagined:

Interviewees in Cefn Mawr painted a picture of a close-knit, friendly and family oriented village. This community had been built around local industry which provided jobs, investment and a sense of local purpose and identity. Industrial employment had, however, been declining in the area for years, threatening individuals' livelihoods and the whole community. In this context, while aware of and concerned about the health risks associated with pollution, the presence of the factory was often vigorously defended. The relationship between pollution and ill-health, although clearly of concern, was treated as a risk that was part of local life. One woman commented; "we've put up with it for so long, to me it's not a problem now." (Burningham and Thrush 2003: 530) 
Perceptions of pollution are associated with emotional investment of residents in a particular location. In addition, these perceptions are related to whether they also think they have agency to act in response to the circumstances. Surprisingly, often people who feel trapped in the landscape with little political and economic opportunities, to either move elsewhere or improve their situation, are the ones who express strong concerns about being "trapped" in a polluted environment (Bickerstaff 2004). Again, Burningham and Thrush (2003: 227) argue that rather than solutions being developed in response to problems, situations often become problematic "only if solutions are apparent." Sometimes the identification of environmental problems contribute reasons for social and economic demands that are already on the table linking demands for environmental and social justice.

In an example of a multinational mining project in New Caledonia, Horowitz (2010) found that employees joined local protest groups against their own employer, because their trust of the company was influenced by long-term social relationships and group affiliations. According to Horowitz (2010: 623) "[r]ather than emphasizing the advantages of employment for themselves and their families, though, these villagers focused on benefits for the country as a whole. They viewed the project as an important part of a long-term development strategy in which multinational mining companies could provide inputs of money and infrastructure that could lead, in the long run, to higher standards of living for all citizens." Overall, local responses to industrial development are mediated by a heterogeneous array of discourses in relation to the different identities at play among local residents (cf. Horowitz 2011). For example, in Tuzla, the stigmatization of place as polluted has resulted in the construction of multiple identities in relation to the local perceptions of the capacity to act among local residents (Castán Broto et al. 2011). Similarly, in a case study of a conflict around a landfill in Durban, South Africa, Leonard (2012) emphasizes how the conflict is structured around class and ethnic lines, rather than simply as a conflict between livelihoods and environmental hazards.

These examples highlight the fundamental contingent nature of concerns about environmental pollution, that depend on the historical relationships between the industry and the local residents and the capacity of residents to imagine themselves as part of a community engaged in collective action. The idea that there is a trade-off between environmental quality and employment security (or economic stability) is false because quality of life depends on both environmental quality and economic stability. Rather, claims about environmental pollution are subject to the complex history of power relations and interactions between the industry, the governmental organizations and the public and the environmental response.

Ultimately, this is a question about the local legitimization of the coal-fired power plant and what those whose lives are affected by industrial pollution perceive as acceptable. The concept of 'social contract' has been used in the business literature in an attempt to explain the limits of fairness in the relationship between business and society. This concept is borrowed from Enlightenment philosophers, most notably Hobbes, Locke and Rousseau, who used it in different ways to explain how (and why) communities may expect to relinquish part of their freedoms in exchange for the establishment of a social order that guarantees the maintenance of the remaining freedoms. ${ }^{2}$ For example, studies of corporate social responsibility looking at the role of businesses in society approach microsocial contracts to show explicit or implicit agreements that are binding within an identified community of industries and stakeholders (Garriga and Mele 2004).

In contrast to recent enthusiasm regarding the idea of the social contract, Martha Nussbaum has argued that the concept does not offer a viable solution to solve problems of global justice. In particular, she is concerned about the emphasis on seeking mutual benefits for all parties and the lack of recognition of the different possibilities for access that such a contract would provide for all the parties (Nussbaum 2006). The social contract approach, thus, is hindered by the problem of representing the participants as equals who should cooperate for mutual advantage. In the case of residents living with pollution associated with an industry, a contractual approach fails to explain the limited choice that local residents may have regarding the presence and development of an industrial facility, particularly when it is considered a national priority, as is the case of the coal energy industry in Bosnia and Herzegovina. If the social contract is not an appropriate base to develop a normative system to balance power struggles within society, it may offer little to improve the fairness of siting industrial facilities.

Instead, I use the concept of social contract as a metaphor for how the industry is integrated within the social and physical landscape, and how a system of relationships develops between industry and the people, determining what a particular group is willing to accept for the development of the industry. With this metaphor I am trying to describe the processes of institutional legitimization whereby an industry may be or may not be collectively accepted as a fair deal in terms of the package of presences, rather than benefits and impacts that this business offers to a community. This package comprises not only economic security and employment but also contributions to a sense of identity and purpose and a caring attitude toward the whole system of socio-ecological relations in which the particular industry is embedded. Other aspects of this social contract may emerge contingent to the location and historical context in which the industry is set.

\footnotetext{
${ }^{2}$ Although the three thinkers explore the concept of 'social contract' they used it to justify very different types of governments.
} 
The presence of a social contract, a history of togetherness, does not guarantee fairness: such negotiations reflect class differences and are developed through a history of huge power imbalances. Thus, in addition to asking how environmental pollution is constructed in Tuzla, it is also important to examine the question of how industry, residents and other stakeholders construct through a process of continuous negotiation a social contract whereby the industry's legitimacy is accepted or rejected within that particular context, and the process whereby local residents reject and contest the status quo.

\section{The case of coal ash pollution in Bosnia and Herzegovina}

The city of Tuzla, in Bosnia and Herzegovina $(\mathrm{BiH})$, has a long history of industrial development shaped by a dramatically redefined political system in the wake of the international conflict and the resulting shift from a socialist to a 'consocionalist' political system. ${ }^{3}$ A $2.7 \mathrm{~mW}$ plant close to the coal mine, Kreka, in the outskirts of Tuzla, started operating in 1906 and closed in 1956. In 1959, a new thermal-power plant, Thermoelektrana Tuzla (TEP), was established in Tuzla; the final phase of construction, with the plant already in operation, concluded in 1978. This plant is currently the largest energy production unit in $\mathrm{BiH}$ with a net production of 2,806 gWh in 2006, which accounts for 58\% of the thermal energy production and $44 \%$ of the total energy production in the country (RECOAL 2009). In the post war environment, the reliance of the country's economy on coal is bigger than ever.

The international conflict during 1992-1995 had a considerable impact on the production of electricity in the country. Energy plants were strategic objectives and often targets of shelling and bombings. The conflict was followed by an effort to reconstruct the facilities and infrastructure in the energy sector. Another major impact of the war was the sudden transformation of the institutional and economic conditions for electricity production. The Dayton Agreement, ${ }^{4}$ a political accord to stop the armed confrontation in 1995, divided the country into two main entities, the Federation of Bosnia and Herzegovina (FBiH) and Republika Srpska (RS), and one independent district (Brčko). Each entity had developed a constitution during the war; the RS being conceived as a unitary state divided into municipalities and the $\mathrm{FBiH}$ as a federation of smaller territorial units, the Cantons, which in turn split into several municipalities (for a detailed account see Ramet 2005). In addition, the Dayton Agreement established ethnic quotas of "constituent peoples" (Croat, Bosniak and Serb) ${ }^{5}$ set to guarantee that each group has equal influence in decision-making. The effect of the agreement is that government and economic organizations have also become divided along ethnic lines:

In fact, the framework agreement now confirms negative aspects of ethnic division across all areas of social life by treating such differences of identity as best managed by territorial separation. Parallel education systems, separate institutions and different communal narratives based on an ethnocentric worldview are widening the cultural gap between ethnic communities. (Halilovich et al., 2006: 4)

Furthermore, the transition to a market economy meant that the former Yugoslavia socialist ideologies were replaced by neoliberal discourses of capital investment and profitability. Recently, the energy sector in $\mathrm{BiH}$, under the guidance of international organizations, has followed the trend toward deregulation of the power industry. New laws on electricity in each of the two entities in which the country was divided followed the publication of a law on transmission, regulation and system operation of electricity in BiH. ${ }^{7}$ These institutional changes have had a considerable impact on the functioning of the utility companies. For example, TEP Tuzla has seen large investments in modernizing its infrastructure, such as the reconstruction of three of its seven generation blocks, the changes to automatic controls, and modernization of the boilers. This work has improved its generation capacity $(709 \mathrm{~mW})$ and extended the lifetime of the plant. Now, the company plans to build new blocks to increase the plant generation capacity by $50 \%$. Some analysts argue that $\mathrm{BiH}$ 's potential for electricity production is underexploited and could emerge into a prosperous economic sector (Lekić 2008). Thus, the energy sector is regarded as central to the country's development strategy. The main reason to be optimistic about the energy sector is BiH's considerable coal reserve; it is estimated at 5,464 million metric tonnes (34\% brown coal and 66\% lignite) (Lekić 2008). Despite the growing importance of

\footnotetext{
${ }^{3}$ This system, unique to $\mathrm{BiH}$, allows for the co-governing in the country by three presidents along ethnic divisions.

${ }^{4}$ Signed in Paris on 14 December 1995, the Dayton Agreement ended the Bosnian international conflict (1992-1995) and established its national Constitution. Bosnia and Herzegovina is the only country in the world whose constitution was written in a language other than the official language of the country (English).

${ }^{5}$ The three groups of "constituent peoples" are virtually indistinguishable; they also speak mutually intelligible languages. The only feature that allows for their differentiation is their religion (Croats are characterised as being Catholic, Serbs as Orthodox and Bosniaks as Muslim).

${ }^{6} \mathrm{BiH}$ is commonly referred as an example of 'consociationalism'.

${ }^{7}$ Law on transmission, regulation and system operation of electricity in Bosnia and Herzegovina (Official Gazatte of BiH, 7/2002); Law on electricity in the Federation of $\mathrm{BiH}$ (Official Gazette of the $\mathrm{BiH}$ Federation 41/2002, 24/2005 and 38/2005); and Law on electricity in the RS (Official Gazette of RS 66/2002, 29/2003, and 86/2003).
} 
hydropower (there are 14 plants in the country), coal is likely to continue shaping the energy sector in the coming decades.

These changes have occurred in the context of a profound cultural transformation throughout the country, from the socialist regime of former Yugoslavia to the multi-party, federal system of Bosnia and Herzegovina. The Marxist-inspired values of the former Yugoslavia recognized the centrality of labor to both society and the economy. Since the 1950s, workers were given the right to decision-making within their companies, then called organizations of associated labor. The relationship between individuals and the different institutions that provided jobs, such as mines, the power plant and associated chemical industries, remained at the centre of individuals' understanding of the self. Moreover, working in the industry could give local communities access to decision-making about some aspects of environmental management. The working class communities laboring in the coal mines, the power plant and associated industries are today in a very different situation. In the new system, however, this relationship has been eroded, as unemployment has skyrocketed and the workers' councils - characteristic of the former Yugoslavia self-management systemhave disappeared. This has been accompanied by growing protests about the impacts of the industry on human and environmental health. This has been salient in the coal industry, where modernization has led to a slash in the number of jobs provided to local communities, while local communities have organized protests against the public health and environmental risks posed by the coal industry.

From 2005 to 2011, I investigated environmental protests in working-class communities in the periurban areas around Tuzla. Among other things, I wanted to understand what changes in the relationship between local residents and the industry could explain the heightening or lowering of local concerns about environmental pollution. Every situation resulted in a specific kind of dialogue that I shared with local residents, trying to understand their main preoccupations, and how the shadow of the power plant and its environmental risks shaped their lives. I carried out qualitative interviews among government officials, industrialists, NGOs and local residents during the period spanning from April 2005 to August 2008. Some of these interviews were carried out as part of the multi-national project RECOAL (Reintegration of Coal Ash Disposal Sites in the Western Balkans), led by environmental and agricultural engineers from the University of Agriculture in Vienna, and partially funded by the European Union. Additional research was carried out independently, contributing to my doctoral thesis. Exploratory interviews carried out during 2005 among diverse stakeholders exposed an ongoing conflict about environmental pollution in Tuzla, heightened by the local claims about the impacts of pollution on their health and livelihoods, but most interviewees tracked the emergence of these concerns to the early 1990s. On this basis, semi-structured interviews were carried out during the spring of 2006 ( $n=51$, only local residents) and during the summer of 2008 ( $n=21$, including local residents, institutional representatives and non-governmental organization [NGO] activists) which explicitly addressed the factors that may have heightened environmental awareness. A follow up visit with further informal interviews was carried out in October 2011.

\section{Accounts of the emergence of environmental pollution concerns}

When asked about their beliefs about the environment in the past, several interviewees expressed nostalgia for the socialist regime of former Yugoslavia, explaining that their quality of life had worsened. They told me that services provided by the former socialist system, such as pensions, health services or employment security, have disappeared while the privatization process has resulted in a sharp rise in unemployment and the concentration of resources in a few hands. Work was defined as a fundamental part of life by most interviewees, and unemployment was pointed out as jeopardizing the future of their local communities. Sead, a middle aged man active in local politics told me "There are fewer and fewer jobs, less industry and all the other things which are necessary for a normal life, for having a normal job, for simply communicating." 8 Another woman, Hasane, explained how her life has been challenged: "Before the war (...) I had my store, my shop," she says, "and we, my husband and I, lived a normal life, worked. Everything was more normal than now. Salaries were more regular and people worked more."

Most interviewees lamented the lack of interest by politicians or plant managers in labor and its significance. More than fifteen years after the end of the international conflict, the country is still undergoing continuous adjustments without a normalization of either the political or economic situation. Instead, some local interviewees argue, industry focused only on profits while authorities (other than the local municipality, which has limited agency to act) did not acknowledge that the national priority of producing energy was posing a local burden in the form of pollution and environmental degradation. This has direct consequences for the acceptability of pollution. Interviewees explain that the industry was part of a system that "brought them good": the harm they suffered was acceptable in the context of the benefits which ensured the continuity of their community. They often emphasized that there was employment for everyone, and therefore, people were able to develop alternative strategies to cope with pollution. For example, workers could count on a reliable health service that provided them what they considered reliable advice about their health and the potential risks in their environment.

\footnotetext{
${ }^{8}$ Names have been changed to protect the anonymity of interviewees.
} 
The demand for employment made by local residents goes hand in hand with demands for people's participation in decision-making within TEP and other industries. These demands are built on their past experiences. One of the characteristics of the self-management system of the former Yugoslavia was that workers had a greater share of influence within "socially owned companies" in which workers could intervene, albeit in a limited fashion, in decision-making. Following Edvard Kardelj's theory of associated labor, workers were given the right to decision-making within their companies, then called "organizations of associated labor" (Damachi and Seibel 1982). Thus, working in the industry may have given local communities access - if perhaps only symbolic - to decision-making about some aspects of environmental management. Workers' groups exercised a degree of control over the industry's environmental decision making. Alongside its limitations (notably economic ones), the "self-management system" may also have had significant perceived social benefits, in this case, contributing to a sense of ownership of TEP by the local communities.

Today, in contrast, local demands have been extended from the maintenance of a quality of life to the preservation of their environment. As in other transition countries, understandings of what is a "good life" have changed in parallel with material changes to their quality of life since 1989 (see also Illner 1998). Interviewees often reflected on the emergence of a collectively shared environmental discourse. For instance, Faruk, a middle-aged male local resident, explained that expressing discontent about environmental problems was against the general dogmas of industrialization and development that preoccupied the country during the former regime, and therefore was considered reactionary or "anti-revolutionary." He felt that no common action could be taken under this premise. This line of thinking implies that the reason why local people did not take action to defend the environment was that they were afraid that this would have compromised their lives within a totalitarian state.

Alongside individuals who felt coerced by the state, however, some interviewees pointed out that environmental awareness did exist in former Yugoslavia. Research on the environment and civil society in Bosnia and Herzegovina also suggests that the environmental movement received intellectual and scientific support from several sectors within socialist society (see also Fagan 2006). This resonates with the opinions expressed by some local residents. Mehmed, formerly the municipal representative of the local community, explained: "this notion of ecology didn't appear from this government and multi-party elections." According to him, people in these communities "were aware of the environmental problem much earlier." By "notion of ecology" Mehmed refers to the awareness of the problem of pollution and the actions of the community to protect their environment. Mehmed contests the idea that the "notion of ecology" has only emerged after the transition to a multi-party system. Instead, those who live in the local community were aware of environmental problems much earlier. He uses the word "notion" to refer to an understanding about ecology which is not necessarily well articulated in coherent political discourses. Instead, environmental issues were intrinsically linked with their everyday lives and articulated in a more casual fashion. For instance, citizens' demands put forward in workers' assemblies during the 1980s moved TEP to establish soil cover on abandoned coal ash disposal sites.

Thus, the capacity of residents in working class communities around Tuzla to mobilize action against TEP's pollution builds upon their pre-war experiences in which action was not articulated through environmental NGOs. Rather, as part of labor unions, women's groups and producers associations who articulated claims to secure employment, and concerns about the long-term sustainability of the community and its environs, simultaneously. Yet, these movements face difficulties. While before the war local residents were confronted with the need to articulate their concerns within the accepted line of the ruling party in Belgrade, today they find themselves isolated and forgotten. While in the pre-war situation the concern was to avoid being "too loud", in the post-war context no shout is loud enough, because within the fragmented institutional system their voices fall on deaf ears. In the best of cases, residents' demands are in the hands of institutions such as the municipality that lack the resources or power to address them. The claims against TEP are cautious: both local residents and institutional representatives acknowledge that the energy industry is part of any conceivable future. Thus, the terms in which such future is negotiated are highly unequal, as demonstrated by the failures of the municipality to enforce environmental sanctions against TEP.

After the war, a closely-knit network of internationally funded NGOs were able to articulate the discourse of environmental pollution in a new fashion. In the context of the transition from socialism to multiparty elections, two parallel transformations occurred. The industry adopted capitalist management models of competitiveness and production, putting profitability requirements at the heart of their business discourse. Simultaneously, a host of organizations, funded mostly with international aid during the late 1990s and early 2000s, articulated western-inspired discourses of environmental protection and human rights. In the recent past, international aid and dependent non-governmental organizations have faded away, leaving behind a few groups that were able to capitalize on their ability to localize global discourses and enroll local residents in their actions. In contrast, the discourses of profitability have flourished at the heart of local industries that now look to international investors for promises of new capital and economic growth. Having this situation administered by the government, which is locally perceived as inefficient at best and corrupt at worst, local residents observe with despair how neither government nor non-governmental organizations are able to address their concerns about their personal and environmental health. 
Yet, local residents have taken numerous actions to mobilize authorities to do something about their situation. In Tuzla, mobilization has been made possible by two forms of self-organization: one involving the continuation of structures from the former Yugoslavia, such as women's groups, and local committees; the other involving the self-organization of new groups specifically concerned with environmental pollution whose members often received training by internationally-funded NGOs. In terms of environmental protection, this may be the major legacy of internationally funded non-governmental activity in Bosnia and Herzegovina in the post-war years. These groups act together through the Mjesna Zaenica or local community, which hosts frequent debates about issues of local concern. For example, in 1998, activists from the local Eco-green group, the women's group, and political and labor representatives organized a protest that stopped the construction of a new coal ash disposal site in a former opencast coalmine that is today a cherished site of recreation for the local communities. In 2000, the same groups, mediated by a politician from a non-nationalist coalition, brought before the Federal parliament a resolution for the protection of the environment by the local communities around TEP which was eventually adopted and later, just as a nationalist President took power, dropped again. Today, in 2012, these local groups are still the main voice articulating local concerns, in the face of a revival of proposals for new disposal sites in the surrounding areas of these communities.

\section{Proposals for the future}

Local residents' accounts of the environmental risks are embedded in parallel accounts of the economic and political situation. Local residents explain the interaction of a wide range of social and economic factors linked with environmental and health risks (Castán Broto 2013). "[B]efore the advent of industry, this area had clean rivers, open-air swimming pools, and parks where people could meet" said Hamid, a local activist. He continues;

However, with the advent and development of industry, everything was taken away from us. It was taken away thanks to the coalmine which, due to coal exploitation from pits and opencast mines damaged the land. This was all done for the needs of electrical power production in TEP. That's why I closely link the economic situation to responsibilities of air pollution. Because those people in the industry mutually acknowledge each other. Who takes which piece of cake it's well-known... It's well-known by higher positions but not by ordinary citizens and residents... So, because of that, they should now pay us back: developing the sewage system; making roads; supplying these local communities with drinkable water; stopping the water reductions, so we can tackle this problem of cleaning and maintaining; not further expanding the disposal sites, etc, etc. That would compensate for what was taken from us.

Hamid mentions only a few of the multiple facets of the problem of coal ash and air pollution resulting from the production of electricity in Tuzla: clean rivers, parks, coal exploitation, electrical power production, the industrial decline, corruption, the sewage system; the roads; water supply; compensation. Local residents present a holistic understanding of environmental problems, including the numerous social and political factors. The conclusion is that solving the problem of pollution requires both environmental remediation solutions and political economic actions targeted at the root causes that create the conditions of pollution and prevent local communities from taking appropriate measures to rectify the problem. What "was taken from them" has to be recognized.

This is associated with a sense that the local communities are sacrificed for the sake of electricity production and the economic growth of the country. Residents assign TEP a clear responsibility for the dangers associated with pollution (Castán Broto 2012). Thus, community members feel that TEP is responsible for providing something back to the community to protect or compensate it from those dangers. Some of the actions may be directed to the physical elimination of the anomalies themselves. However, the demands from the local communities go beyond the mere regeneration of the environmental state: something else has to be brought back to compensate for them being put in danger. TEP has been slow in recognizing any claims from the local communities, although during my last visit in October 2011 TEP representatives claimed to be interested in developing a more constructive relationship with these communities. In the meantime, lack of trust in TEP and local institutions has developed and local residents perceive that TEP is not interested in their problems and is willing to let their communities suffer (or even disappear) to produce electricity.

Moreover, compensation is not a straightforward matter: meaningfully valuing cleanliness, habits or health is impossible. Putting a price on these conditions poses serious ethical considerations. Local people accept TEP's presence, but the perceived unfairness of the situation cannot be reversed by money: only by "internalizing" TEP within the community. In order to do that, TEP is compelled to share its benefits. For example, local residents ask TEP to allocate free electricity supply to the local people or the establishment of a tax, which could be reinvested in the environment, known locally as the "eco-dinar," to be paid to the community through the local municipality. Talking in the name of the Women's Group to which she belongs, Mahira explained that they "would be satisfied if they at least started to give us this eco-dinar, and we could 
be able to put certain pressure on the Municipality of Tuzla, on the Cantonal government to carry out some of our plans for the protection of the environment in cooperation with the Service for spatial planning, with the ecological associations and citizens' assemblies." While improving their situation is seeing as a necessary collective effort, local residents propose measures (like the eco-dinar) which require the industry to recognize its responsibility for declining living conditions in the working class communities in the peri-urban area of Tuzla.

Another proposal put forward by several interviewees was to share the benefits of TEP in the form of, for example, free electricity supply or district heating. This was put forward by one representative who highlights it as a political demand, Muhamed:

We are fighting to get heating from the Electroplant, because TEP has such an excess of thermal energy... This steam goes into the air; the Electroplant requires minimum resources just to provide heating for this threatened community. It could supply us with heating only from the excess steam going up in the air. (...) In addition, we pollute ourselves because we are poor, we burn plastic, rubber; we don't have money to buy real wood so that we could heat ourselves on real wood and real coal. The people burn all kinds of things, we add to the pollution.

Local people are concerned about the pollution caused by individuals who burn plastic and brown coal. Moreover, burnt coal and plastic are commonly dumped in rubbish containers, causing additional pollution. Even if this pollution is not comparable with that from TEP's chimneys, local people believe that eliminating it would improve the state of the environment. By giving free heating, TEP can contribute toward the overall wellbeing of the community. Claiming free heating has three sources of legitimization: 1) social, which addresses the claimed need of internalizing (if only partially) TEP within the local community; 2) economic, which takes advantage of a by-product of TEP (the excess of heating); and 3) environmental, which reduces air pollution caused by household heating. Although free heating will not solve local environmental problems altogether, it points to the way in which a new form of social contract could be developed, not to mutually benefit both TEP and local residents, but rather, to share with local residents the benefits that TEP is already obtaining. In October 2011 infrastructure for district heating was being laid down in some of the communities affected, although there were ongoing disputes about whether the infrastructure was going to reach all the communities affected and whether the heating would be provided free of charge. In any case, the implementation of this measure symbolizes a qualitatively different step in the negotiations between TEP and the local communities that is now being recognized as well by the leaders of environmental activist groups.

The problem of coal ash disposal belongs, in local residents' accounts, to a wider context with multiple dysfunctional aspects. Pollution, lack of infrastructure, unemployment, massive migration, poor health, and political abandonment are some of the most prominent difficulties that local residents experience in this particular context. In particular, pollution and unemployment are two facets of the same problem: industrial decline. In Tuzla, the industry (and TEP is the rule, not the exception) struggles to compete in a globalize economy, let alone protect the environment. Industrial representatives argue that, at the moment, they are unable to provide even more funds for pollution abatement. Local residents point out that these are not separate problems. Rather, they consider health and ecological risks together with the economic situation. The economic difficulties of local residents affect their capacity to deal with the risks of pollution and protect their environment. This has moved some local residents to develop economically productive activities on the coal ash disposal sites. Lack of resources, whether at the individual or at the municipal level, has prevented actions to protect the local communities and ecosystems from the spread of dust (e.g. wind barriers, erosion protection works), from the pollution of underground waters (e.g. the establishment of filtering stations), or even from any interaction with the disposal sites (e.g. adequate signaling and fencing of the sites and associated water). Their failure to have an impact on their overall situation seems to be driven local residents to a desperate situation.

\section{Beyond the trade-off between environmental quality and security of employment}

Listening to local residents in Tuzla, what moved me the most was their genuine interest in negotiating a future for themselves and their children. Their talk was burdened by stories of migration, poor health and unemployment. Their frustrations were directed at the ongoing destruction of the landscape they built their lives on. They understood that their health and environmental risks that affect them cannot be read in isolation, without regard for the political and historical factors that have caused them. Their accounts of pollution were related to both the physical experience of pollution and the social and political relationships between the industry and local residents. Ultimately, the fundamental imbalances in the relationship between residents and the power generation industry conditions the possibility of reversing the damage done to the environment and to the fabric of society. Using their experiences local residents advance proposals that, rather than trying to establish a new social contract, were pointed towards opening up avenues for an ongoing process of negotiation and a reinvention of the role of the industry. 
In Tuzla, since the late 1960s, TEP not only provided local jobs (indeed, only a small proportion of people were employed in TEP), but also, it contributed to the economic stability of the region while supporting and attracting other economic activities. The industry as a whole may have contributed to a sense of identity and value of local communities, particularly when local residents felt that they had some sort of control over TEP through workers' councils and by putting pressure on local community representatives (cf. Burningham and Thrush 2003). In the social contract labor was central, not only to revalorize the presence of the industry in the region in its relationships with local residents but also as a link between the region and shared national values.

This has changed radically after the international conflict in the 1990s and the subsequent transition to a market economy. The market economy has not been implemented in a vacuum, since some modest market reforms had already been incorporated in the self-management system since the economic crises of the mid1960s. But the economic regimes have changed, together with some institutions that provided social stability to workers' communities in the former Yugoslavia. The economic transition, together with associated political changes and the rise of nationalism have brought wider changes on the social, economic and political discourses and values of the industry. Three key developments in TEP have found outright rejection among the local communities: 1) the implementation of discourses of market liberalization and profitability and the rejection of what are now regarded as old socialist values of labor and community protection; 2) limiting the access of local residents to any form of decision-making relating to TEP through the de-legitimization of the industrial relations institutions of former Yugoslavia and the centralization of decision-making in Sarajevo; 3) the limited responses to publicly expressed concerns about pollution and infrastructure. In addition, two other factors have supported the rise of environmental concerns in Tuzla: the lack of agency of the local political institutions to either respond to local demands or regulate TEP; and the rise of environmental protection narratives promoted in the campaigns of internationally-funded NGOs. The result is a vociferous environmental movement, grounded on local concerns, which so far has not been successful in legitimizing their claims, but which seems to be gaining prominence and making modest gains against the idea that TEP remains unwilling to re-define its ill-conceived social contract with local residents. Recent attempts by the municipality to re-invent the city's industrial image, for example by promoting its artificially constructed salt lakes as a tourist attraction (The Economist 2012), highlights that this movement is not alone in seeking economic alternatives which restore, rather than degrade, the natural heritage of the city. ${ }^{9}$

Perceptions of pollution are related to emotional investments in places, which develop over time. They are also linked to how members of society imagine themselves as members of the collective community. This case resonates with the conclusion that people who express concerns about being "trapped" by the pollution are those with little political and economic opportunities to either move elsewhere or improve their situation (Bickerstaff 2004). Thus, once such an understanding of the environmental pollution problem is constructed, the solutions proposed to solve it are often directed at improving the livelihoods of community stakeholders. In the case of Tuzla, all the solutions proposed (the eco-dinar, the district heating) are calls for a radical redefinition of TEP's role in the community: however modest or ambitious, all these proposals have in common a challenge to neoliberal discourses of profitability and a claim to TEP's responsibility for the community's well-being. This challenge transcends the geographical boundaries of Tuzla to contest the nationalist and neoliberal-oriented political establishments in Bosnia and Herzegovina, for failing to attend to its citizens' most basic needs. The claims of local residents about how their working class status limits their capacity to cope with pollution establishes a direct relationship between environmental justice and workingclass studies. Local residents have shown considerable resilience in their use of fuels and the cultivation of the coal ash disposal sites, but this comes at the expense of bringing to the community new health and environmental risks for which the industry should also be made responsible.

In using the metaphor of social contract I am attempting to sum up the evolving historical condition that shapes the relationship between the industry and local residents. I argue that the practice of a social contract is integrated within the social and physical landscape, as a process of explicit or implicit negotiation of what are acceptable environmental and health risks. This metaphor, however, also indicates the key dilemmas of how the landscape is shaped. The relationship between the industry and residents is grounded on inequity: it is historically and politically based, and contributes to reproduced power imbalances. Ultimately, what the working classes in Tuzla and other areas in Bosnia and Herzegovina may be suffering is the consequences of a hugely failed social contract.

During my interviews with local residents in Tuzla, it became obvious that the choice between employment security and environmental protection is impossible. Employment security and environmental protection are not opposing concerns; rather, they are important aspects of the same interlinked issue. There is no rational choice between employment and the environment: both are needed for the survival of the

\footnotetext{
${ }^{9}$ Thanks to the anonymous reviewer for her/his perceptive observations regarding recent developments in the city of Tuzla, including this example.
} 
community. Thus, to characterize public understanding of pollution as a trade-off between environmental quality and economic security misrepresents the complexity of local perceptions of pollution. Instead, these perceptions need to be understood as contingent upon a social contract that values healthy, working-class communities and environmental stewardship. Community perceptions are the result of unexpected interactions between the positive and threatening aspects of industry, the broader cultural vision of a future imagined community, and the role of industry in such a future.

\section{References}

Baxter, J. 2009. A quantitative assessment of the insider/outsider dimension of the cultural theory of risk and place. Journal of Risk Research 12: 771-91.

Baxter, J., and D. Lee. 2004. Understanding expressed low concern and latent concern near a hazardous waste treatment facility. Journal of Risk Research 7 (7): 705 - 29.

Bickerstaff, K. 2004. Risk perception research: socio-cultural perspectives on the public experience of air pollution. Environment International 30 (6): 827-40.

Bickerstaff, K., and G. Walker. 2003. The place(s) of matter: matter out of place - public understandings of air pollution. Progress in Human Geography 27 (1): 45-67.

Bickerstaff, K., and G. Walker. 2001. Public understandings of air pollution: the 'localisation' of environmental risk. Global Environmental Change 11 (2): 133-45.

Burningham, K., and G. Cooper. 1999. Being constructive: social constructionism and the environment. Sociology 33 (2): 297-316.

Burningham, K., and D. Thrush. 2004. Pollution concerns in context: a comparison of local perceptions of the risks associated with living close to a road and a chemical factory. Journal of Risk Research 7 (2): 21332.

Burningham, K, and D. Thrush. 2003. Experiencing environmental inequality: the everyday concerns of disadvantaged groups. Housing Studies 18 (4): 517 - 36.

Castán Broto, V., Burningham, K., Carter, C., Elghali, L. 2011. Stigma and attachment: performance of identity in an environmentally degraded place. Society and Natural Resources, 23 (10): 952-968.

Castán Broto, V. 2012. Exploring the lay/expert divide: the attribution of responsibilities for coal ash pollution in Tuzla, Bosnia and Herzegovina. Local Environment 18(7): 879-895

Castán Broto, V. 2013. Symbolic violence and the politics of environmental pollution science: the case of coal ash pollution in Bosnia and Herzegovina. Antipode. In press.

Damachi, U.G., and Seibel H.D. (eds.). 1982. Self management in Yugoslavia and the developing world. London: Macmillan.

Edelstein, M.R. 2004. Contaminated communities: coping with residential toxic exposure. Cambridge: Westview Press.

Fagan, A. 2006. Neither 'North' nor 'South': the environment and civil society in post-conflict BosniaHerzegovina. Environmental Politics 15 (5): 787 - 802.

Garriga, E. and Melé, D. 2004. corporate social responsibility theories: mapping the territory. Journal of Business Ethics 53 (1): 51-71.

Greider, T., and L. Garkovich. 1994. Landscapes - the social construction of nature and the environment. Rural Sociology 59 (1): 1-24.

Halilovich, H., Phipps, P., Adams, R., James, P. and S. Bakalis. 2006. Editorial: pathways to reconciliation. Local-Global 2: 4-8.

Hannigan, J. 2006. Environmental sociology - a social constructionist perspective. NY: Routledge, 1995.

Horowitz, L.S. 2010. "Twenty years is yesterday": science, multinational mining, and the political ecology of trust in New Caledonia. Geoforum 41 (4): 617-626.

Horowitz, L.S. 2011. Interpreting industry's impacts: micropolitical ecologies of divergent community responses. Development and Change 42 (6): 1379-1391.

IMF. 2010. Bosnia and Herzegovina: staff report for the first review under the stand-by arrangement. Washington: IMF.

Kasperson, J.X., Kasperson, R.E., Pidgeon, N., and Slovic, P. 2003. The social amplification of risk: fifteen years of research and theory. In N. Pidgeon, R.E. Kasperson and P. Slovic (eds.) The social amplification of risk. Cambridge: Cambridge University Press.

Illner, M. 1998. The changing quality of life in a post-communist country: the case of Czech Republic. Social Indicators Research 43(1): 141-70.

Lekić, A. 2008. Energy sector in Bosnia and Herzegovina: current status and plans. In K. Hanjalic, R.van de Krol, and A. Lekić (eds.) Sustainable energy technologies: options and prospects. Springer. 
Leonard, L. 2012. Another political ecology of civil society reflexiveness against urban industrial risks for environmental justice: the case of the Bisasar landfill, Durban, South Africa. Singapore Journal of Tropical Geography 33 (1): 77- 92.

McGee, T.K. 1999. Private responses and individual action: community responses to chronic environmental lead contamination. Environment and Behavior 31 (1): 66-83.

Nussbaum, M. 2006. Frontiers of justice: disability, nationality, species membership. Harvard: Harvard University Press.

Ramet, S. 2005. Thinking about Yugoslavia: scholarly debates about the Yugoslav breakup and the wars in Bosnia and Kosovo. Cambridge: Cambridge University Press.

RECOAL. 2009. Handbook on treatment of coal ash disposal sites (Bilingual Edition English/Bosnian). Vienna: BOKU.

Relph, E. 1976. Place and placelessness. London: Pion.

The Economist. 2012. Bosnia's Salt Lake City. Eastern approaches blog. Available online at http://www.economist.com/blogs/easternapproaches/2012/07/tuzlas-lakes (last accessed 20/12/2012).

Zonabend, F. 1993. The nuclear peninsula (Translated from French by J.A. Underwood). Cambridge: Cambridge University Press.

\begin{abstract}
People's experiences of a polluted space are intimately linked with their relative concerns for quality of life and livelihoods. Thus quality of environment and security of employment are two closely related issues in social conflicts over environmental pollution. Rather than being implicated in a trade-off relationship, environmental quality and job provision are both part of the life of community residents. Bringing together the literature on the political ecology of environmental conflicts and the social constructionist literature on public perceptions of environmental risks, this article argues that the working class and disadvantaged sections of society are often confronted with alliances between the industry, institutions and other stakeholders which may serve to legitimate a particular configuration of things in which the appropriation of some resources by the industry is regarded as legitimate. However, these arrangements are unstable: they are subject to constant renegotiation between the social groups implicated. Thus, how the emergence of concerns about the local environment relates to preoccupations about the state of the local economy is related to a process whereby these relationships are constructed and re-negotiated. These questions are analyzed using a case study of environmental pollution from coal-energy production in the city of Tuzla, Bosnia and Herzegovina. The case shows that both concerns for the environment and unemployment are articulated simultaneously in the context of industrial pollution, together with the redefinition of the socio-economic landscapes of post-industrial Tuzla.
\end{abstract}

Keywords: Environmental pollution, employment, working-class life, social constructionism, Bosnia and Herzegovina

\title{
Résumé
}

La recherche a montré que les expériences d'un espace pollué sont intimement liées à des préoccupations relatives à la qualité de la vie et les moyens de subsistance. Ainsi, la qualité de l'environnement et de la sécurité de l'emploi sont deux questions étroitement liées à des conflits sociaux sur la pollution de l'environnement. La qualité de l'environnement, et l'offre d'emplois, font tous deux partie de la vie des communautés à proximité d'une source de pollution. En rassemblant la littérature sur l'écologie politique des conflits environnementaux, et la construction sociale des risques environnementaux, cet article soutient que les communautés les plus défavorisés sont souvent confrontés à des alliances. Ce sont entre l'industrie, les institutions et les autres parties prenantes, de sorte que l'appropriation des ressources par l'industrie est considérée comme légitime, à un certain niveau. Toutefois, ces dispositions ne sont pas stables: ils sont soumis à renégociation constante entre les groupes sociaux impliqués. Ainsi, comment l'émergence de préoccupations au sujet de l'environnement local se rapporte à des préoccupations sur l'état de l'économie locale est liée à la façon dont les relations sont construites et renégocié. Ces questions sont analysées à l'aide d'une étude de cas de la pollution de l'environnement par la production d'énergie au charbon dans la ville de Tuzla, en Bosnie-Herzégovine. Cette affaire montre que les deux préoccupations - l'environnement et le chômage - sont articulées simultanément dans le contexte de la pollution industrielle, ainsi que la redéfinition des paysages socio-économiques de Tuzla dans sa situation actuelle post-industrielle.

Mots-clés: pollution de l'environnement, l'emploi, la vie ouvrière, constructivisme social, la BosnieHerzégovine 


\section{Resumen}

Las experiencias de un espacio contaminado de la gente que vive en él están íntimamente relacionadas con las preocupaciones existents con respecto a su calidad de vida y sus medios de subsistencia. Por tanto, la calidad del medio ambiente y la seguridad de empleo son dos temas estrechamente relacionados dentro de conflictos sociales por la contaminación ambiental. En lugar de tener una relación de intercambio, la calidad ambiental y la provisión de empleo forman parte de la vida de los residentes de la comunidad. Este articulo traza conexiones entre las literaturas de ecología política el construccionismo social para analizar esta pregunta dentro de la percepción de los riesgos ambientales. De este modo, este ensayo sostiene que la clase obrera y los sectores desfavorecidos de la sociedad a menudo se enfrentan a alianzas entre la industria, las instituciones de gobierno y otras partes interesadas cuyos argumentos legitimizan la apropiación de recursos por parte de la industria. Sin embargo, estos arreglos son inestables, y están sujetos a la renegociación constante entre los grupos sociales implicados. Por lo tanto, la emergencia de preocupaciones sobre el medio ambiente y el estado de la economía local depende de un proceso continuo de re-negociacion. Estas cuestiones se analizan en un estudio de caso sobre conflictos producidos por la contaminación ambiental de la producción de energía a carbón en la ciudad de Tuzla, en Bosnia y Herzegovina. El caso muestra que tanto la preocupación por el medio ambiente y el desempleo se articulan simultáneamente en el contexto de contaminación industrial, a la vez que se produce una redefinición de los paisajes socio-económicos de la Tuzla post-industrial.

Palabras clave: Pollucion ambiental, empleo, vida de clase obrera, construccionismo social, Bosnia and Herzegovina 